\title{
Isozyme patterns and protein profiles in neuromuscular disorders
}

\author{
Y H EDWARDS*, T D TIPLER*, J A MORGAN-HUGHES $\dagger$, J S NEERUNJUN $\ddagger$, \\ AND D A HOPKINSON* \\ From *the MRC Human Biochemical Genetics Unit, The Galton Laboratory, University College London, \\ Wolfson House, 4 Stephenson Way, London NWI 2HE; †the National Hospital for Nervous Diseases, \\ Queen Square, London WC1; and $\ddagger$ the Neonatal Research Unit, Institute of Child Health, \\ Hammersmith Hospital, London W12 OHS
}

SUMMARY The isozyme patterns of six different enzymes and the polypeptide profiles of soluble proteins have been examined in muscle biopsy specimens from 74 patients with a wide variety of neuromuscular disorders. About half of the samples showed unusual features in at least one, and often several, of the enzymes and proteins tested. The extent of the biochemical abnormalities was roughly proportional to the severity of the disorders. In all cases the unusual isozymes and polypeptide profiles seemed to reflect a reversion to the fetal pattern of gene expression. However, this change appeared to occur in extant muscle and was not dependent on the appearance of new muscle fibres.

Among the enzymes, phosphoglycerate mutase followed by creatine kinase appeared to be the most sensitive index of muscle disorder. The extent of the change in the muscle creatine kinase isozyme pattern was not correlated with the levels of serum creatine kinase activity.

Unusual isozyme patterns of creatine kinase, ${ }^{1}$ aldolase $^{2}$ and lactate dehydrogenase ${ }^{3}$ have been observed in diseased muscle from man and other vertebrate species. There are at least two possible explanations for the appearance of such patterns: either they reflect some general change in the patterns of gene expression in deteriorating muscle cells or the regeneration of muscle and the appearance of newly differentiating myoblasts. The three enzymes involved have some features in common. They each occur at relatively high levels in adult muscle and are determined by multiple gene loci which show alteration in the pattern of expression during intrauterine development. In each case the patterns of isozyme activity seen in diseased muscle more closely resemble those of the fetus.

Creatine kinase is of special interest to those engaged in research on muscular dystrophies since raised activity in serum has proved to be valuable in the diagnosis of these disorders (for a review see Tyler $^{4}$ ), and the appearance of the MB creatine

§Present address: Scherling Chemicals, Burgess Hill, Sussex RH15 9NE.

Received for publication 18 July 1981 kinase isozyme in the serum and in the muscle may help in the recognition of female carriers of the sex linked Duchenne type of progressive muscular dystrophy. ${ }^{5-7}$

The value of creatine kinase as a serum marker for muscle disorders lies in the occurrence of a muscle specific isozyme which is present in relatively high concentrations in muscle. However, there are other enzymes present in similar or even greater quantities in adult muscle which also show muscle specific isozyme patterns but which have scarcely been investigated as serum markers of muscular abnormalities. Among them are lactate dehydrogenase, aldolase, phosphoglyceromutase, acid phosphatase, and carbonic anhydrase. The purpose of the present investigation was to explore the isozyme patterns of these enzymes in muscle biopsy specimens from patients with neuromuscular disorders and to assess their potential diagnostic value. At the same time the profile of soluble proteins in abnormal muscle and in normal adult and fetal muscle was compared. The occurrence of 'fetal-like' isozyme patterns and unusual protein profiles and their physiological significance in the progress of muscle disease is discussed. 
Materials and methods

Fetal skeletal muscle samples (10 to 24 weeks' gestation) were obtained from abortions, and infant and adult skeletal muscle was obtained at necropsy. Tissue samples were stored at $-20^{\circ} \mathrm{C}$ until used. Muscle biopsy samples were obtained from the Muscle Research Unit of the Hammersmith Hospital, London, and from the National Hospital for Nervous Diseases, London. The muscle samples were taken by open wound biopsy, usually from limb muscle, from subjects between 9 months and 72 years of age and included examples of a wide variety of muscle disorders. In most cases information about the histological appearance of the biopsy was available, and in some cases an estimate of the level of serum creatine kinase was also provided. The upper limit of the normal range of serum creatine kinase activity was taken as $120 \mathrm{IU} / \mathrm{l}$.

Extracts of the sarcoplasmic proteins were prepared in an aqueous solution as described by Tipler et $a,^{8}$ except in cases where the biopsy sample weighed $0.5 \mathrm{~g}$ or less. In these instances the sample was finely minced with scissors and disrupted in $50 \mu l$ of distilled water by sonication, using a Dawe Soniprobe. The resultant suspension was centrifuged at $85000 \mathrm{~g}$ for 30 minutes and the supernatant used for analysis.

The sarcoplasmic protein profiles were analysed using vertical slab polyacrylamide gel electrophoresis, both in the presence and absence of the anionic detergent sodium dodecyl sulphate (SDS) using the buffer system of Laemmli. ${ }^{9}$

The isozyme patterns of creatine kinase (CK), aldolase (ALD), lactate dehydrogenase (LDH), enolase (ENO), phosphoglyceromutase (PGAM), and acid phosphatase (ACP) were analysed using horizontal starch gel electrophoresis and specific staining procedures as described by Harris and Hopkinson. ${ }^{10}$

\section{Results}

\section{ANALYSIS OF PROTEIN AND POLYPEPTIDE PATTERNS}

The sarcoplasmic protein profiles of 74 biopsies from subjects with a variety of different neuromuscular disorders were examined using conventional and SDS polyacrylamide gel electrophoresis, and the patterns were compared with normal adult and fetal muscle.

Fourteen of the samples from subjects with muscle abnormalities showed polypeptide profiles which differed from the normal adult skeletal muscle pattern and an example is shown in fig 1 together with examples of apparently normal polypeptide profiles from other patients. The polypeptide

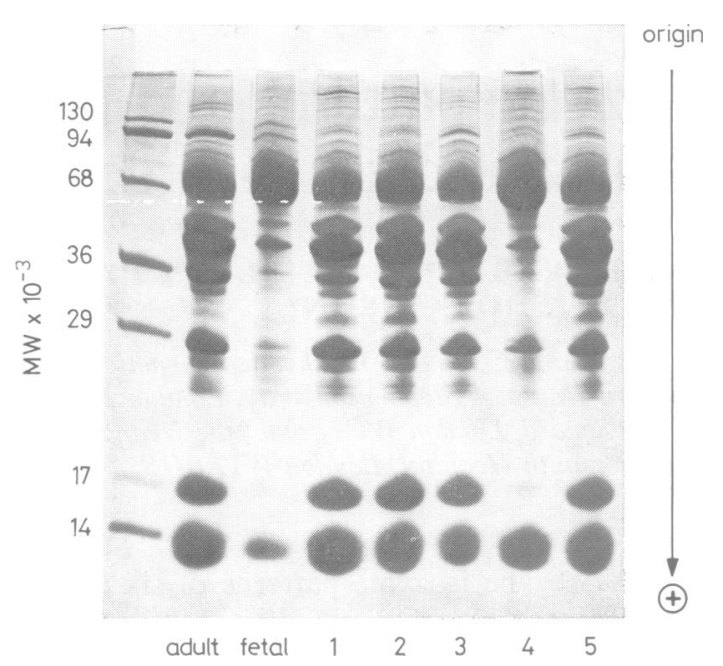

FIG 1 Polypeptide patterns detected after SDS electrophoresis of skeletal muscle from a normal adult, an 18-week fetus, and patients with various neuromuscular disorders. The clinical diagnosis in each case is as follows: (1) porphyria cutanea tarda, (2) muscle weakness because of rheumatoid arthritis, (3) muscle pain,

(4) inflammatory myopathy, (5) muscle pain and weakness associated with steroid treatment for chronic bronchitis.

pattern exhibited by sample 4 , a male of 47 years with inflammatory myopathy, closely resembles that of muscle from an 18 week fetus. The decreased prominence of myoglobin (molecular weight 17000 ) and of the polypeptides of molecular size 45000 , 36000 (which probably represents the enzyme glyceraldehyde-3-phosphate dehydrogenase), and 32000 are particularly noticeable, although the component of molecular size 29000 , which has been identified as the skeletal muscle-specific form of carbonic anhydrase (CAIII), ${ }^{11}$ is only partially depleted. This pattern of apparent protein deficiency was found in all samples showing unusual polypeptide profiles.

In three subjects the polypeptide profile was indistinguishable from that of fetal muscle and is designated as the $F$ type in table 1 . In the other 11 cases the profile was intermediate (I) between the typical adult and fetal patterns. The findings are summarised in table 1 . It is noticeable that this effect is found in a wide variety of different disorders and not all cases of any particular disease exhibit unusual polypeptide profiles.

\section{ANALYSIS OF ISOZYME PATTERNS}

Six different enzymes were examined by electrophoresis in the pathological material and in normal 
TABLE 1 The occurrence of unusual sarcoplasmic polypeptide profiles in skeletal muscle of subjects with various neuromuscular disorders

\begin{tabular}{|c|c|c|c|}
\hline Diagnosis & $\begin{array}{l}\text { No } \\
\text { tested }\end{array}$ & $\begin{array}{l}\text { No of subjects } \\
\text { with unusual } \\
\text { polypeptide } \\
\text { profile }\end{array}$ & $\begin{array}{l}\text { Type of } \\
\text { change }\end{array}$ \\
\hline Duchenne muscular dystrophy & 4 & 2 & $\begin{array}{ll}1 \mathrm{~F} \\
1 \mathrm{I}\end{array}$ \\
\hline $\begin{array}{l}\text { Becker's X linked muscular } \\
\text { dystrophy }\end{array}$ & 2 & 1 & I \\
\hline $\begin{array}{l}\text { Limb girdle dystrophy } \\
\text { Non-specific muscular }\end{array}$ & 6 & 1 & $1 \mathrm{I}$ \\
\hline $\begin{array}{l}\text { dystrophy } \\
\text { Spinal muscular atrophy, }\end{array}$ & 1 & 1 & I \\
\hline $\begin{array}{l}\text { autosomal recessive } \\
\text { Progressive muscular }\end{array}$ & 3 & 2 & $2 \mathrm{I}$ \\
\hline dystrophy & 1 & 1 & I \\
\hline Mitochondrial myopathy & 3 & 1 & I \\
\hline Inflammatory myopathy* & 7 & 4 & $\begin{array}{l}2 \mathrm{I} \\
2 \mathrm{~F}\end{array}$ \\
\hline Vacuolar myopathy & 2 & 1 & I \\
\hline
\end{tabular}

*2 of these patients showed type II atrophy.

muscle specimens. These include creatine kinase (CK), lactate dehydrogenase (LDH), aldolase (ALD), enolase (ENO), phosphoglyceromutase (PGAM), and acid phosphatase (ACP). These enzymes were chosen for analysis since they exhibit tissue specific isozyme patterns determined at multiple gene loci which show differential expression during the development of normal muscle cells. ${ }^{12}$ The details of the muscle isozymes seen in adult and fetal life are summarised in table 2. The muscle samples varied considerably in size so that it was not always possible to examine all the enzymes in every sample.

\section{CREATINE KINASE (CK)}

Tzvetanova ${ }^{1}$ has described changes in the creatine kinase isozyme patterns in diseased muscle samples in which characteristically there is a decrease in intensity of the adult MM isozyme and the appearance of the fetal MB isozyme, which is made up of polypeptides determined by the $C K_{B}$ and the $C K_{M}$ loci. Forty-three biopsies from subjects with various neuromuscular disorders were analysed for creatine kinase in this study and, of these, eleven showed changes similar to those described by Tzvetanova. ${ }^{1}$ The intensity of the MB isozyme was variable, in some cases appearing as a very weak component (for example, samples $a$ and $b$ in fig 2 , gel 1), while in others it was a prominent zone (sample e). This latter sample was from a 30-year-old female with McCardle's syndrome and resembles the pattern usually seen in 23-week fetal muscle.

\section{LACTATE DEHYDROGENASE (LDH)}

Changes in LDH isozyme patterns in dystrophic
TABLE 2 Developmental changes in the electrophoretic patterns of several human enzymes in muscle. ${ }^{12}$ The fetal specimens were obtained from 10 to 24 weeks' gestation and the adults were all over the age of 20 years. The relative staining intensities of the isozymes are indicated by a simple + - system. + indicates trace activity sometimes detected and - indicates no detectable activity

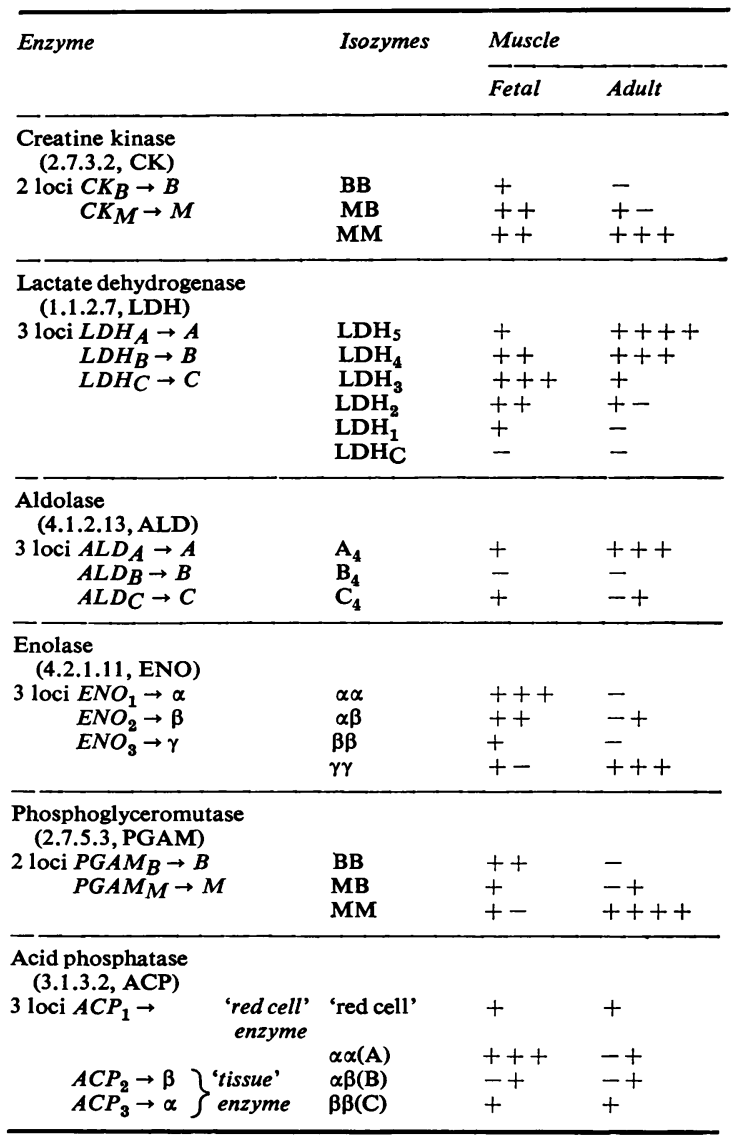

muscles have been described ${ }^{3}$ and can be summarised as a general increase in the isozymes containing polypeptides determined by the $L D H_{B}$ locus together with an apparent decrease in the homotetrameric $\mathrm{LDH}_{5}$ isozyme containing polypeptides determined by the $L D H_{A}$ locus. Fourteen biopsies from affected subjects were examined for lactate dehydrogenase in the present study and, of these, five showed isozyme patterns not typical of normal adults but more similar to those of fetal muscle. Three examples of these unusual patterns are illustrated in fig 2, gel 2, which also shows the pattern seen in a normal fetus (sample b). Samples 

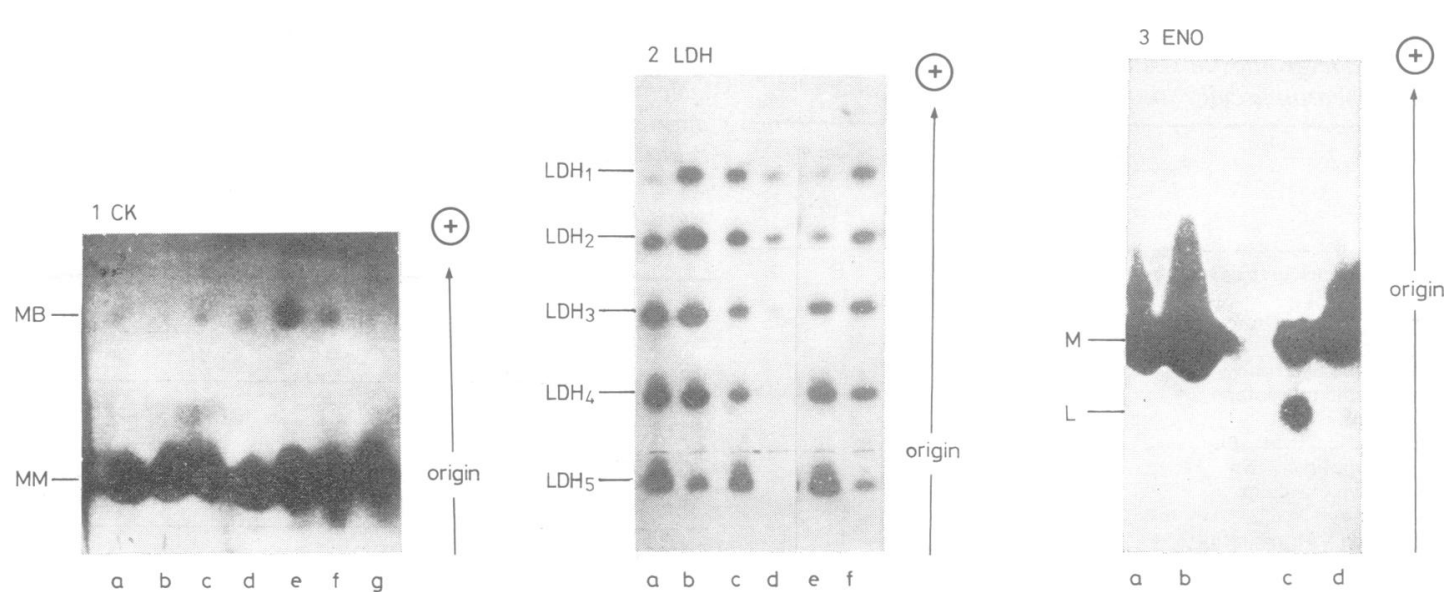

FIG 2 Isozyme patterns in skeletal muscle biopsy specimens from patients with various neuromuscular disorders. The diagnoses in each case are given. (1) Creatine kinase: (a) peroneal muscular dystrophy, (b) non-specific muscular dystrophy, (c) myasthenia gravis, $(d)$ muscle pain (steroid treatment), $(e)$ McCardle's syndrome, $(f)$ motor neurone disease, ( $g$ ) normal. (2) Lactate dehydrogenase: (a) limb girdle dystrophy, (b) normal fetus, (c) mitochondrial myopathy, $(d)$ and $(e)$ Duchenne muscular dystrophy, $(f)$ mitochondrial myopathy. (3) Enolase: (a) spinal muscular atrophy, (b) Duchenne muscular dystrophy, (c) inflammatory myopathy, (d) normal adult muscle.

c and f, from subjects with mitochondrial myopathy, more closely resemble the fetal than the adult pattern. In samples from two subjects with Duchenne muscular dystrophy one (sample d) shows a very atypical pattern in which only the isozymes $\mathrm{LDH}_{1}$, $\mathrm{LDH}_{2}$, and $\mathrm{LDH}_{3}$ are detected, while the other (sample e) has an LDH pattern identical to that of normal adult muscle.

\section{ALDOLASE (ALD)}

In 1968 Schapira et $a l^{2}$ described fetal-like aldolase isozyme patterns in dystrophic muscle from rabbit and chicken. In fetal muscle both the $A L D_{A}$ and $A L D_{C}$ loci are equally active, but as development proceeds the activity of $A L D_{C}$ considerably declines so that in adult muscle the $A_{4}$ isozyme is the major component. The aldolase isozymes in 34 biopsies were examined and two showed atypical aldolase patterns more closely resembling those seen in the fetus. This was most striking in a subject with Becker's X linked dystrophy and in the other case, limb girdle myopathy, the aldolase pattern was intermediate in appearance between the normal fetus and adult.

\section{ENOLASE (ENO)}

In normal adult muscle the locus $\mathrm{ENO}_{3}$ is active, determining the $\mathrm{M}$ isozyme. However, in fetal muscle two other loci, $E N O_{1}$ and $E N O_{2}$, are also active determining the 'fast', 'intermediate', and $L$ isozymes. $^{13}$ of 58 biopsy samples examined for enolase, seven exhibited the $\mathrm{L}$ isozyme. Fig 2, gel 3, illustrates the isozyme patterns in three biopsy samples and a necropsy sample of normal adult muscle. The presence of the $L$ isozyme in sample $c$, a 51-year-old female with inflammatory myopathy, is in marked contrast to the usual isozyme pattern which was found in the other samples shown on the gel, from subjects with spinal muscular atrophy and Duchenne muscular dystrophy.

ACID PHOSPHATASE (ACP)

In adult muscle, the locus $A C P_{3}$ determines the $\mathrm{C}$ isozyme, but in fetal muscle ( $<24$ weeks' gestation) both $\mathrm{ACP}_{2}$, which determines the $\mathrm{A}$ isozyme, and $A C P_{3}$ are active, so that $\mathrm{A}$ and $\mathrm{C}$ isozymes with trace amounts of the heterodimeric $B$ isozyme are usually seen. Of 29 biopsies examined for acid phosphatase, two, one from a case of alcoholic myopathy and the other from a case of oculopharyngeal myopathy, exhibited a fetal-like isozyme pattern.

\section{PHOSPHOGLYCEROMUTASE (PGAM)}

This dimeric enzyme is determined by two gene loci, $P G A M_{M}$ and $P G A M_{B}$. In fetal muscle, the $P G A M_{B}$ locus is most active but as development proceeds the $P G A M_{M}$ locus increases in activity. This results in the major fetal isozyme, $\mathrm{BB}$, being gradually replaced by the $\mathrm{MB}$ and $\mathrm{MM}$ isozymes. The MM isozyme is the major adult form. The isozyme pattern of phosphoglyceromutase appeared 
TABLE 3 Summary of the analysis of polypeptide and enzyme electrophoretic patterns of skeletal muscle from subjects with various neuromuscular disorders. $F$ indicates pattern typical of fetal muscle and I a pattern intermediate between that of an adult and fetus

\begin{tabular}{|c|c|c|c|c|c|c|c|}
\hline \multirow[t]{2}{*}{$\begin{array}{l}\text { Severity of } \\
\text { disorder }\end{array}$} & \multicolumn{7}{|c|}{$\begin{array}{l}\text { No of subjects showing unusual electrophoretic } \\
\text { pattern/total No of subjects examined }\end{array}$} \\
\hline & Protein & $C K$ & $P G A M$ & ENO & $A L D$ & $L D H$ & $A C P$ \\
\hline \multicolumn{8}{|l|}{$\mathbf{A}$} \\
\hline $\begin{array}{l}\text { Severe } \\
\text { Moderate } \\
\text { Mild }\end{array}$ & $\begin{array}{l}7 / 15 \\
5 / 30 \\
2 / 29\end{array}$ & $\begin{array}{l}4 / 8 \\
5 / 20 \\
2 / 15\end{array}$ & $\begin{array}{l}3 / 3 \\
7 / 7 \\
1 / 3\end{array}$ & $\begin{array}{l}3 / 9 \\
3 / 26 \\
1 / 23\end{array}$ & $\begin{array}{l}1 / 7 \\
0 / 17 \\
1 / 10\end{array}$ & $\begin{array}{l}2 / 3 \\
2 / 7 \\
1 / 4\end{array}$ & $\begin{array}{l}0 / 3 \\
1 / 15 \\
1 / 11\end{array}$ \\
\hline \multicolumn{8}{|l|}{ B } \\
\hline Severe & 1F & 4F & 3F & 三F & $1 \mathbf{F}$ & 2F & - \\
\hline Moderate & $\begin{array}{l}2 \mathrm{~F} \\
3 \mathbf{I}\end{array}$ & $\begin{array}{l}4 \mathbf{F} \\
1 I\end{array}$ & $\begin{array}{l}3 F \\
4 I\end{array}$ & $3 \mathrm{~F}$ & - & $1 \mathbf{F}$ & $\underline{1 F}$ \\
\hline Mild & $\overline{2 I}$ & $2 \mathbf{F}$ & $\overline{1 I}$ & $\underline{1 F}$ & $\overline{1 I}$ & 1F & $\underline{1 F}$ \\
\hline
\end{tabular}

to be a particularly sensitive index of muscle abnormality since 11 out of 13 biopsies showed isozyme patterns more typical of fetal muscle than adult muscle.

SUMMARY OF ELECTROPHORETIC FINDINGS Table 3 summarises the results from the analysis of the polypeptide and enzyme electrophoretic patterns. The severity of the neuromuscular disorder in each case has been roughly classified as either severe, moderate, or mild according to the clinical findings, the serum CK levels, and the histological picture of the biopsy. This assessment was made at the time the biopsy was taken and analysed. Of the 74 biopsies examined, 15 were classified as severe, 30 as moderate, and 29 as mild disorders.

Atypical electrophoretic patterns were found in a wide range of disorders but the extent to which the isozyme patterns diverged from normal was not characteristic of any particular disease, and an abnormality of one particular isozyme pattern was not necessarily accompanied by changes in the others or in the polypeptide profile. Furthermore, subjects with the same disorder did not necessarily show similar types of isozyme pattern. However, the greatest incidence of fetal-like patterns occurred among the group classified as severe.

The isozyme patterns of phosphoglyceromutase are especially interesting since this enzyme is apparently a more sensitive indicator of muscle abnormality than creatine kinase. Among 13 cases where both phosphoglyceromutase and creatine kinase were tested, the isozyme patterns were concordant in seven instances (classified A or F). In one case the $C K$ was graded as fetal $(F)$ in contrast to the PGAM graded as intermediate (I). However, in the other five cases the PGAM was relatively more like the fetal pattern than the CK, and indeed four of these samples showed a CK pattern identical to that of normal muscle.

\section{GENERAL FEATURES}

The classification of the patients into severe, moderate, or mild groups was in part based on the level of serum creatine kinase. In 19 cases, information was available about both the CK isozyme pattern in the biopsy and the level of serum CK at the time the biopsy was obtained. There appeared to be no correlation between the occurrence of the 'fetal' MB isozyme of CK in the biopsy material and the level of the enzyme in the serum. Three biopsies showed a very pronounced 'fetal' CK isozyme pattern, practically indistinguishable from that observed in specimens obtained from mid-term pregnancy. One of these was found to have the highest serum CK level in the series $(2830 \mathrm{U} / 1)$, but the other two $(170$ and $240 \mathrm{U} / \mathrm{l})$ were only moderately above what was considered the upper limit of the normal range (120 U/l). A fourth case which showed a CK pattern intermediate between fetal and adult skeletal muscle had a relatively low normal (17 U/1) serum CK activity. The level of serum CK activity observed in the other biopsy specimens covered the full range from low normal $(11 \mathrm{U} / \mathrm{l})$ to considerably raised $(900 \mathrm{U} / \mathrm{l})$, but in each case only the CK $\mathbf{M}$ isozyme was observed (see appendix). There was no correlation between the age of the patient when the biopsy was taken and the appearance of the 'fetal' MB isozyme. Thus, it seems that the level of serum CK does not reflect a change in the expression of the $C K_{M}$ and $C K_{B}$ loci.

We also attempted an overall analysis of the relationship between the histological appearance of the biopsy specimens and the biochemical data. The muscle of Duchenne patients of all ages was grossly abnormal histologically with signs of active fibre degeneration especially in young patients (3 to 6 years). Patches of muscle fibre regeneration occurred in the muscles of young Duchenne patients but were much less obvious in the older group (7 to 10 years) and, apart from a single case (biopsy No 15), the samples used in the present study came from this latter group. In contrast, in the muscles from patients with inflammatory myopathy, the regions in which there was evidence of muscle breakdown were always interspersed with significant areas of active regeneration, regardless of the patient's age. There was apparently no relationship between the occurrence of newly formed myotubes and the appearance of a fetal pattern of isozymes or polypeptides since the fetal-like patterns were found most commonly in the Duchenne biopsy material (see appendix). 


\section{Discussion}

Observations made in this study and earlier investigations show that neuromuscular disorders are associated with marked changes in muscle isozyme patterns and polypeptide profiles. These changes appear to be general and consequent upon rather than the cause of the disease process. Furthermore, the changes in the enzymes and other proteins considered in this study are not characteristic of a particular disorder or class of disorders and it is usual to encounter changes of several gene products in any one muscle sample. There is, however, some correlation between the incidence of unusual isozyme patterns and protein profiles and the overall severity of the disorders.

The unusual isozymes are not novel or unique to the disordered muscle but are isozymes normally expressed in fetal life. Similarly, the polypeptide profiles encountered in diseased adult muscle are very similar to those of healthy fetal muscle homogenates. The most likely interpretation of these unusual profiles is that they reflect changes in the patterns of gene expression within the muscle rather than degeneration and degradation of muscle proteins in vivo or in vitro. It is not clear whether the changing patterns of gene expression occur within existing fully differentiated adult muscle cells or reflect the appearance of newly differentiated myotubes. Our evidence from histology and isozyme patterns, particularly in comparisons of the Duchenne and inflammatory myopathy material, suggests that the 'fetal' patterns of gene expression are not inevitably dependent upon successful muscle regeneration and can arise within existing but deteriorating myofibres. That the two phenomena, muscle breakdown and disdifferentiation, can also occur independently is illustrated by the findings on creatine kinase in serum and muscle biopsy specimens. It has been shown in this study, and previously by Cao et al,,$^{14}$ that within the same subject there is no correlation between serum CK activity and the occurrence of the creatine kinase MB isozyme in skeletal muscle. The presence of the MB isozyme presumably indicates genetic disdifferentiation of existing myofibres or normal differentiation of newly developing muscle fibres or both, whereas the rise in the serum creatine kinase activity reflects muscle fibre degeneration with leakage of protein into the circulation.

The creatine kinase MB isozyme is sometimes detected in the serum of patients with neuromuscular disorders $^{6} 7$ and it has been suggested that its presence is a reflection of cardiac muscle degeneration. The MB form of creatine kinase is often regarded as an isozyme marker of cardiac but not skeletal muscle. However, as the present studies demonstrate, the MB isozyme is not restricted to cardiac muscle. It accounts for a significant proportion of the total skeletal muscle CK activity in almost all of the biopsy specimens tested which show degenerative change and fetal-like isozyme patterns, and could certainly have contributed substantially to the serum CK activity.

Analysis of the creatine kinase isozymes in serum and muscle biopsy specimens provides quite a good index of muscle degradation and disdifferentiation in various disorders of muscle function, but there are several other enzymes which may be equally or even more informative. Enolase (ENO) and phosphoglycerate mutase (PGAM) for example were found to be especially valuable in the present work on muscle biopsy material and it would be interesting to investigate the isozymes and overall levels of activity of these enzymes in the sera of patients with neuromuscular disorders. ENO and PGAM each show an isozyme pattern specific to fetal muscle, and fetal-like isozymes of both these enzymes have been observed in several of the pathological muscle biopsy specimens. Indeed, PGAM may prove to be a relatively more sensitive marker enzyme than CK, since fetal patterns of PGAM were found in several instances where no other biochemical changes were observed and where the CK isozymes were indistinguishable from normal.

Analysis of the polypeptide profiles of soluble muscle proteins by SDS gel electrophoresis appears to be comparable to the CK isozyme patterns as an index of neuromuscular disorders. The changes which have been observed in two of the major proteins of skeletal muscle, myoglobin and the muscle specific carbonic anhydrase CAIII, appear to reflect a change in the pattern of gene expression within the muscle and a reversion to the fetal state, since myoglobin is absent and CAIII is present at lower than usual concentrations. This parallels the situation observed in a mid-term fetus; myoglobin is not detected until after 24 weeks' gestation and CAIII remains at less than half of the normal adult levels until birth. ${ }^{15}$

The possibility that the unusually low levels of these and other polypeptides reflect degeneration and protein leakage into the serum cannot be totally discounted. Myoglobin has been identified in the serum of some subjects with degenerative muscle disorders, such as Duchenne muscular dystrophy. ${ }^{16}$ CAIII has also been detected in the serum of patients with Duchenne dystrophy, ${ }^{17}$ although in lower amounts than might be expected in the case of this abundant protein. It appears that leakage of muscle proteins is not random and is not related to the relative abundance, size, or solubility of the proteins. 
APPENDIX Electrophoretic data on a series of muscle biopsies from subjects with various neuromuscular disorders

\begin{tabular}{|c|c|c|c|c|c|c|c|c|c|c|c|}
\hline \multicolumn{2}{|c|}{ Biopsy No and diagnosis } & \multirow{2}{*}{$\begin{array}{l}\text { Age and } \\
\text { Sex }\end{array}$} & \multirow{2}{*}{$\underset{C K(I U / l)}{\operatorname{Serum}}$} & \multirow{2}{*}{$\begin{array}{l}\text { Severity } \\
\text { of } \\
\text { disorder }\end{array}$} & \multicolumn{7}{|c|}{ Electrophoretic data } \\
\hline & & & & & Protein & $C K$ & $P G A M$ & ENO & $A L D$ & $L D H$ & $A C P$ \\
\hline 1 & $\begin{array}{l}\text { Mild mitochondrial myopathy with } \\
\text { ophthalmoplegia }\end{array}$ & $\begin{array}{l}14 \\
M\end{array}$ & 20 & Mild & $\mathbf{A}$ & - & - & $\mathbf{A}$ & 一 & - & 一 \\
\hline 2 & Progressive muscular dystrophy* & $\begin{array}{l}16 \\
F\end{array}$ & 50 & Moderate & $\mathbf{I}$ & - & 一 & $\mathbf{A}$ & - & - & - \\
\hline 3 & Spinal muscular atrophy & $\stackrel{4}{F}$ & 45 & Severe & I & - & 一 & 一 & - & 一 & 一 \\
\hline 4 & Limb girdle dystrophy & 12 & 32 & Mild & $\mathbf{A}$ & $\mathbf{A}$ & - & 一 & - & $\mathbf{A}$ & $\mathbf{A}$ \\
\hline 5 & Mitochondrial myopathy & 12 & 170 & Moderate & $\mathbf{A}$ & $\mathrm{F}$ & $\mathbf{F}$ & $\mathbf{A}$ & $\mathbf{A}$ & $\mathbf{I}$ & - \\
\hline 6 & Duchenne dystrophy & $\begin{array}{r}7 \\
M\end{array}$ & 2830 & Severe & $\mathbf{A}$ & $\mathrm{F}$ & $\mathbf{F}$ & 一 & $\mathbf{A}$ & $\mathbf{F}$ & 一 \\
\hline 7 & Mitochondrial myopathy & $\begin{array}{r}2 \\
\mathbf{M}\end{array}$ & 240 & Severe & I & $\mathbf{F}$ & $\mathbf{F}$ & $\mathbf{F}$ & $\mathbf{A}$ & $\mathbf{F}$ & $\mathbf{A}$ \\
\hline 8 & Duchenne dystrophy & $\begin{array}{r}8 \\
\mathbf{M}\end{array}$ & 1130 & Severe & $\mathbf{I}$ & - & - & $\mathbf{A}$ & - & - & - \\
\hline 9 & Limb girdle dystrophy† & $\begin{array}{l}10 \\
F\end{array}$ & 885 & Moderate & $\mathbf{A}$ & 一 & - & $\mathbf{A}$ & - & - & - \\
\hline 10 & Becker's X linked dystrophy & $\begin{array}{l}10 \\
\mathbf{M}\end{array}$ & 1330 & Severe & I & - & - & $\mathbf{A}$ & - & - & - \\
\hline 11 & Congenital muscular dystrophy & $\begin{array}{l}30 \\
\mathrm{~F}\end{array}$ & 415 & Moderate & $\mathbf{A}$ & 一 & - & $\mathbf{A}$ & - & 一 & - \\
\hline 12 & $\begin{array}{l}\text { Spinal muscular atrophy, autosomal } \\
\text { recessive }\end{array}$ & $\stackrel{9}{\mathrm{~F}}$ & 900 & Moderate & I & $\mathbf{A}$ & - & $\mathbf{A}$ & 一 & 一 & $\mathbf{A}$ \\
\hline 13 & Malignant hyperpyrexia & $\begin{array}{l}30 \\
F\end{array}$ & 320 & Mild & $\mathbf{A}$ & $\mathbf{A}$ & 一 & $\mathbf{A}$ & - & - & 一 \\
\hline 14 & McArdle's syndrome & $\begin{array}{l}15 \\
\mathbf{M}\end{array}$ & 134 & Severe & $\mathbf{A}$ & $\mathbf{A}$ & - & $\mathbf{A}$ & 一 & 一 & - \\
\hline 15 & Spinal muscular atrophy $\ddagger$ & $\begin{array}{r}4 \\
M\end{array}$ & 1699 & Severe & $\mathrm{F}$ & 一 & 一 & $\mathbf{F}$ & - & - & 一 \\
\hline 16 & Myopathy and hypertonia & $\begin{array}{l}9 / 12 \\
M\end{array}$ & 230 & Mild & $\mathbf{A}$ & - & - & - & 一 & - & 一 \\
\hline 17 & Limb girdle dystrophy & $\mathrm{F}^{8}$ & 1548 & Severe & $\mathbf{A}$ & - & 一 & - & 一 & 一 & 一 \\
\hline 18 & Duchenne dystrophy & - & - & Severe & $\mathbf{A}$ & $\mathbf{F}$ & $\mathbf{F}$ & - & $\mathbf{A}$ & $\mathbf{A}$ & - \\
\hline 19 & Becker's X linked dystrophy & $\begin{array}{l}23 \\
\mathbf{M}\end{array}$ & - & Severe & $\mathbf{A}$ & $\mathbf{A}$ & - & $\mathbf{A}$ & $\mathbf{F}$ & - & $\mathbf{A}$ \\
\hline 20 & Muscle pain syndrome & $\begin{array}{l}21 \\
F\end{array}$ & - & Mild & $\mathbf{A}$ & 一 & - & $\mathbf{A}$ & - & 一 & - \\
\hline 21 & Non-specific myopathy & $\begin{array}{l}57 \\
\mathbf{M}\end{array}$ & - & Mild & $\mathbf{A}$ & $\mathbf{A}$ & - & $\mathbf{A}$ & $\mathbf{A}$ & - & $\mathbf{A}$ \\
\hline 22 & Inflammatory myopathy & $\begin{array}{l}51 \\
F\end{array}$ & 一 & Moderate & $\mathbf{F}$ & $\mathbf{A}$ & - & $\mathbf{F}$ & $\mathbf{A}$ & - & $\mathbf{A}$ \\
\hline 23 & Non-specific congenital myopathy & $\begin{array}{l}31 \\
\mathbf{F}\end{array}$ & 6 & Mild & $\mathbf{A}$ & - & - & 一 & 一 & - & 一 \\
\hline 24 & Inflammatory myopathy & $\begin{array}{l}55 \\
F\end{array}$ & 158 & Moderate & $\mathbf{A}$ & - & - & - & 一 & 一 & - \\
\hline 25 & Spinal cord angioma & $\begin{array}{l}62 \\
F\end{array}$ & - & Moderate & $\mathbf{A}$ & 一 & - & 一 & - & 一 & - \\
\hline 26 & Spinal muscular atrophy & $\begin{array}{l}26 \\
\mathbf{M}\end{array}$ & - & Mild & $\mathbf{A}$ & - & - & $\mathbf{A}$ & - & - & - \\
\hline 27 & Focal inflammatory myopathy & $\begin{array}{l}32 \\
F\end{array}$ & 21 & Mild & I & - & - & $\mathbf{A}$ & - & - & 一 \\
\hline 28 & Muscle cramp & $\begin{array}{l}50 \\
\mathbf{M}\end{array}$ & - & Mild & $\mathbf{A}$ & - & - & $\mathbf{A}$ & 一 & 一 & - \\
\hline 29 & Myotonic dystrophy & $\begin{array}{l}41 \\
M\end{array}$ & 78 & Moderate & $\mathbf{A}$ & $\mathbf{A}$ & - & $\mathbf{F}$ & $\mathbf{A}$ & - & $\mathbf{A}$ \\
\hline 30 & $\begin{array}{l}\text { Sjögren's syndrome associated with } \\
\text { myopathy }\end{array}$ & $\begin{array}{l}53 \\
\mathbf{M}\end{array}$ & - & Mild & $\mathbf{A}$ & - & - & $\mathbf{A}$ & 一 & - & 一 \\
\hline 31 & Scapuloperoneal myopathy & $\begin{array}{l}51 \\
\mathbf{M}\end{array}$ & 一 & Moderate & $\mathbf{A}$ & $\mathbf{A}$ & - & $\mathbf{A}$ & - & $\cdots$ & - \\
\hline 32 & Limb girdle dystrophy & $\begin{array}{l}51 \\
\mathrm{~F}\end{array}$ & 525 & Severe & $\mathbf{A}$ & 一 & - & $\mathbf{F}$ & - & 一 & - \\
\hline 33 & Non-specific myopathy & $\begin{array}{l}68 \\
\mathbf{M}\end{array}$ & - & Moderate & $\mathbf{A}$ & $\mathbf{A}$ & 一 & $\mathbf{F}$ & - & - & $\mathbf{A}$ \\
\hline 34 & Facioscapulohumeral dystrophy & - & - & Moderate & $\mathbf{A}$ & $\mathbf{A}$ & - & $\mathbf{A}$ & - & - & $\mathbf{A}$ \\
\hline 35 & Myopathy (alcoholic) & $\begin{array}{l}61 \\
M\end{array}$ & - & Mild & $\mathbf{A}$ & $\mathbf{A}$ & - & $\mathbf{F}$ & $\mathbf{A}$ & - & $\mathbf{F}$ \\
\hline
\end{tabular}


APPENDIX continued

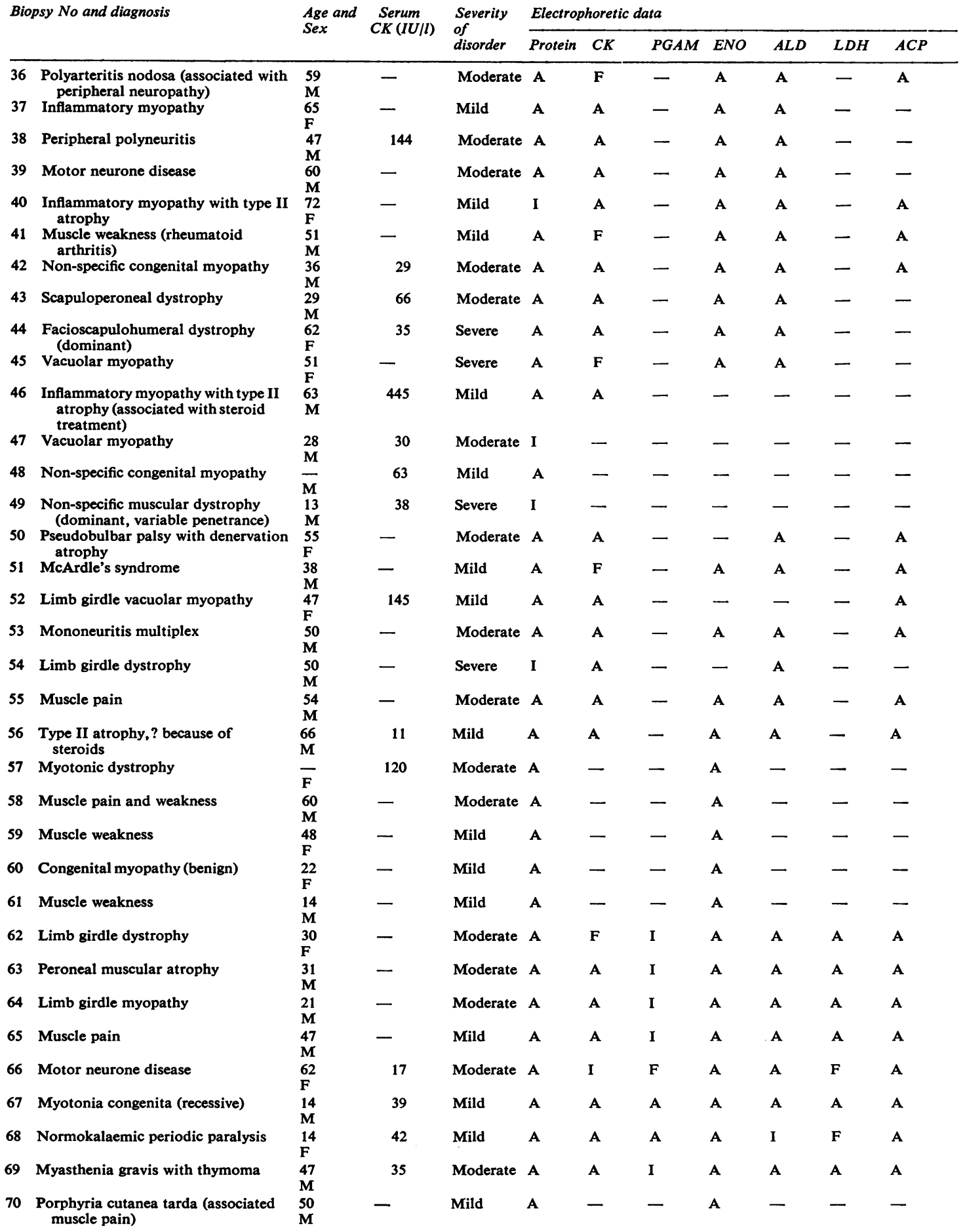




\section{APPENDIX continued}

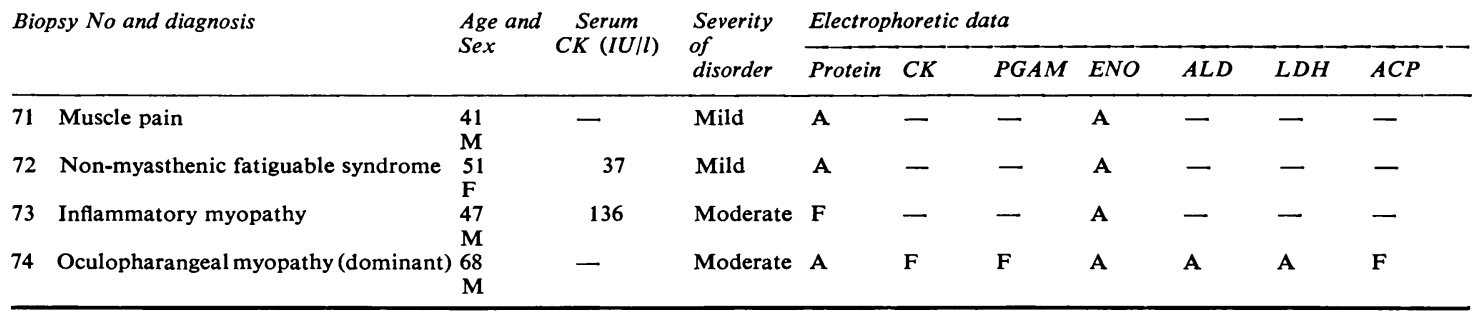

The appearance of the polypeptide profile and isozyme patterns are classified as A, adult-like; F, fetal-like; I, intermediate between the typical adult and fetal patterns.

* Case 2. This patient had a congenital muscular dystrophy complicated by scoliosis and myocardial fibrosis. Her parents were first cousins.

†Case 9. The histological and clinical pictures are not entirely consistent with a usual limb girdle dystrophy. The patient exhibited a focal necrotising type of myopathy with general muscle involvement and deteriorated rapidly after the investigations reported here.

$\ddagger$ Case 15. Provisional diagnosis made at time of biopsy (February 1976). Subsequent investigations suggested a clinical diagnosis of Duchenne muscular dystrophy and data scored as Duchenne in table 1 .

\section{References}

1 Tzvetanova E. Creatine kinase isoenzymes in muscle tissue of patients with neuromuscular diseases and human fetuses. Enzyme 1971;12:279-88.

2 Schapira F, Dreyfus JC, Allard D. Les isoenzymes de la creatine kinase et de l'aldolase du muscle foetal et pathologique. Clin Chim Acta 1968;20:439-47.

3 Schapira F. Isozymes and cancer. Pathol Biol 1970;18: 309-22.

4 Tyler FH. In: Stanbury JB, Wyngaarden JB, Fredrickson DS, eds. The metabolic basis of inherited disease. 3rd ed. New York: McGraw Hill, 1972:1204-17.

5 Kuby SA, Kentel HJ, Keuchiro O, et al. Isolation of the human ATP-creatine transphosphorylases (creatine phosphokinases) from tissues of patients with Duchenne muscular dystrophy. J Biol Chem 1977;252:8382-90.

6 Takahashi K, Shutta K, Matsuo B, Takai T, Takao H, Imura $\mathrm{H}$. Serum creatine kinase isoenzymes in Duchenne muscular dystrophy. Clin Chim Acta 1977;75:435-42.

7 Goedde HW, Christ I, Bentmann HG, Beckmann R, Long H. Creatine kinase isoenzyme patterns in Duchenne muscular dystrophy. Clin Genet 1978;14:257-60.

8 Tipler TD, Edwards YH, Hopkinson DA. Developmental changes in the protein profiles of human cardiac and skeletal muscle. Ann Hum Genet 1978;41:409-18.

9 Laemmli WK. Changes of structural proteins during the assembly of the head of the bacteriophage T4. Nature 1970;227:680-5.

10 Harris H, Hopkinson DA. Handbook of enzyme electrophoresis in human genetics. Amsterdam: North Holland, 1976.
11 Carter N, Jeffery S, Shiels A, Edwards Y, Tipler T, Hopkinson DA. Characterisation of human carbonic anhydrase III from skeletal muscle. Biochem Genet 1979; 17:837-54.

12 Edwards YH, Hopkinson DA. Developmental changes in the electrophoretic patterns of human enzymes and other proteins. In: Ratazzi MC, Scandalios JE, Whitt GS, eds. Isozymes: current topics in biological and medical research. New York: Liss, 1977:20-78.

13 Pearce JM, Edwards YH, Harris H. Human enolase isozymes: electrophoretic and biochemical evidence for three loci. Ann Hum Genet 1975;39:263-76.

14 Cao A, De Virgilliis D, Lippi C, Coppa G. Serum and muscle creatine kinase isoenzymes and serum aspartate amino transferase isoenzymes in progressive muscular dystrophy. Enzyme 1971;12:49-62.

15 Jeffery S, Edwards Y, Carter N. Distribution of CAIII in fetal and adult human tissue. Biochem Genet 1980;18: 843-9.

16 Adornato BT, Kagen LJ, Engel WK. Myoglobinaemia in Duchenne muscular dystrophy patients and carriers: a new adjunct to carrier detection. Lancet 1978 ;ii:499-501.

17 Carter ND, Heath R, Jeffery S. Serum carbonic anhydrase III in Duchenne dystrophy. Lancet 1980;ii:541.

Requests for reprints to Dr Y H Edwards, MRC Human Biochemical Genetics Unit, The Galton Laboratory, University College London, Wolfson House, 4 Stephenson Way, London NW1 2HE. 